\title{
Determination of The Critical Success Factors in Disaster Management Through The Text Mining Assisted Ahp Approach
}

\author{
Halil İbrahim Cebeci ${ }^{1}$, (D) Yasemin Korkut ${ }^{2}$ \\ 1'Sakarya University, hcebeci@sakarya.edu.tr, \\ ${ }^{2}$ Corresponding Author, Yalova University, yasemin.korkut@yalova.edu.tr, +90 (226) 81565 72,
}

Received 18 January 2021; Accepted 5 February 2021; Published online 16 February 2021

\begin{abstract}
In the academic field and as well as the application field, substantial attention has been drawn to coping with disasters. Since natural dangers causing a large proportion of disasters cannot be avoided, attempts to combat disasters have centered on preventing hazards from evolving into disasters through measures and restructuring works taken before, during, and after the disaster. There are many players involved in the disaster management process and many factors are influential in the effectiveness of this process. Among these factors, deciding the critical ones offers significant advantages, particularly in terms of practical studies. Concentrating on a single stakeholder in deciding the factors crucial to the success of this management structure, which has many stakeholders, can cause to ignoring the significant viewpoints of other stakeholder groups. Accordingly, for the evaluation of several success factors achieved as a result of a thorough and systematic literature review, the purpose of our study is to develop a common critical success factor model that will represent both the viewpoints of operational experts and academic experts, who constitute the stakeholders of this domain. Analytical Hierarchy Process (AHP) is utilized to determine the opinions of field experts while the text mining method was used to determine the perspectives of academics. In the study, therefore, a new AHP model assisted by text mining is introduced. Socio-cultural factors were brought to light by the analysis results of the suggested model. It has been determined by the results of the study that these two perspectives are overlapped largely in the organizational field and relatively in socio-cultural, environmental, and legal fields.
\end{abstract}

Keywords: Disaster management, Critical success factors, AHP, Text mining

\section{Introduction}

Natural disasters that have inflicted numerous losses of life and material destruction that worth millions of liras throughout history, cannot be completely avoided or prevented even under today's technological means. Disaster is characterized as the results of natural, technological, or man-made events that lead individuals to endure physical, economic, social, and environmental losses, impact societies by preventing or disrupting normal lives and human activities, and cannot be resolved by the affected community members by using their own resources and methods [1].

The efficient implementation of proactive and reactive actions at different disaster phases will mitigate the harm due to natural disasters and avoid most disasters perceived to be man-made or technological from occurring. In this context, disaster management is a complete process of endeavor that must be carried out by the community to avoid and mitigate disasters, to respond promptly, efficiently, and effectively to the incidents that form the disaster, and to build a safer and more efficient living atmosphere for the people affected by the disaster [2]. In this direction, in terms of taking measures, with the effective management of disasters, it is possible to reduce human losses, environmental, social, and economic damages. The chaos generated by unregulated activities after the disaster can be avoided by carrying out various tasks in a prepared and organized way, by facilitating the return to normal life for people in the disaster zone or by providing a living environment for these individuals in better conditions than before the disaster.

A comprehensive approach that involves multiple stakeholders around the country could be more useful for effective disaster management, instead of concentrating on a single region or specific activities. In this context, it is important for effective disaster management to prioritize the variables and to disclose the crucial factors to enable the properly working of the integrated model, which involves several 
variables. In the extensive literature review performed for the domain, it has been witnessed that studies focusing on critical success factors in disaster management have paid attention to a certain stage or area of disaster management [3-5] or the number of factors examined was rather limited in the studies that paid attention to the whole stages [6]. From this perspective, for the success of a critical area such as disaster management, a more detailed perspective is required.

This topic has been extensively investigated in the academic field since the consequences of disaster management throughout the years are very significant. The substantial accumulation of knowledge that has arisen in this domain should be considered. However, given the significance of the experiences obtained from the practices, a disaster management framework developed only as proposed by academic studies is not sufficient. In van Niekerk's [7] study, which explored whether academic discourse or practical reality must be at the center of disaster management, he claimed that a disaster management system that relies exclusively on the academic context, government, and international and regional organizations spend a substantial amount on activities that do not offer any value. He also claimed that a study would be insufficient to enhance disaster risk mitigation and management without addressing the roots of disaster studies and research in both social and natural sciences. We may conclude that disaster management practitioners are engaged in a complex and continually changing activity in a disaster management system which only depends on practices. Therefore, the result stating that disaster management activities require practical and scientific input is examined. Thus, it is aimed to create a new model in this study whose academic knowledge includes the opinions of the experts who have been working in this field in Turkey and have significant information. In this context, this research attempts to incorporate the knowledge obtained from a systematic and thorough literature review by introducing a model that integrates the perspectives of the field's operational experts, taking into account that an integrated approach that combines academic studies and the viewpoints of practitioners can be beneficial.

9 areas that directly influence the success of disaster management were reported as a result of the literature review undertaken to realize the purpose of the research. Factors indicated at the end of the screening are divided into sub-factor groups under the main factor groups for the scope of these 9 areas. Therefore, the need for managing a hierarchical structure composed of the main factor group, a subfactor group, and the other factors necessitated a new model with a different viewpoint. AHP method has been used for main factor groups and sub-factor groups forming the first two levels of hierarchy and text mining method which will reflect the perspective of academics was applied for the factors that form the lowest level of the hierarchy. Finally, a Critical Success Score (CSS) was calculated for each factor by combining the results of these two analysis methods. The first 20 factors with the highest CSS were evaluated as critical success factors in disaster management.

This research is important in terms of benefiting from the views of both academics and field experts in the field of disaster management and also being a guideline for the translation of academic knowledge into practice by identifying. The study's extensive literature and the model proposal can be anticipated to lead further academic studies.

In the following part of the study, fundamental studies that have determined the main factor groups will be discussed. At the same time, success factors which are derived after the comprehensive literature review performed on main factor groups will be summarized in this part. Thereafter, the results obtained will be evaluated in light of the 3-stage integration model suggested in the study and findings of analyses, and in this context, the limitations of this study will be stated and suggestions for further studies will be presented.

\section{Motivation and Previous Studies}

There are three main phases of activities in effective disaster management planning, namely pre-disaster, disaster response, and post-disaster [8]. These three main phases can be evaluated in five stages: planning and preparation, mitigation, response, recovery, and evaluation [8,9]. However, since each of these processes requires activities such as planning and risk mitigation measures, there is no requirement to pursue one another [10]. At the same time, though it is a matter of obscurity when disasters will occur, 
these studies will not end. The stages of disaster management should therefore not be in a linear form, but in a cycle, as seen in Figure 1 [8-10].

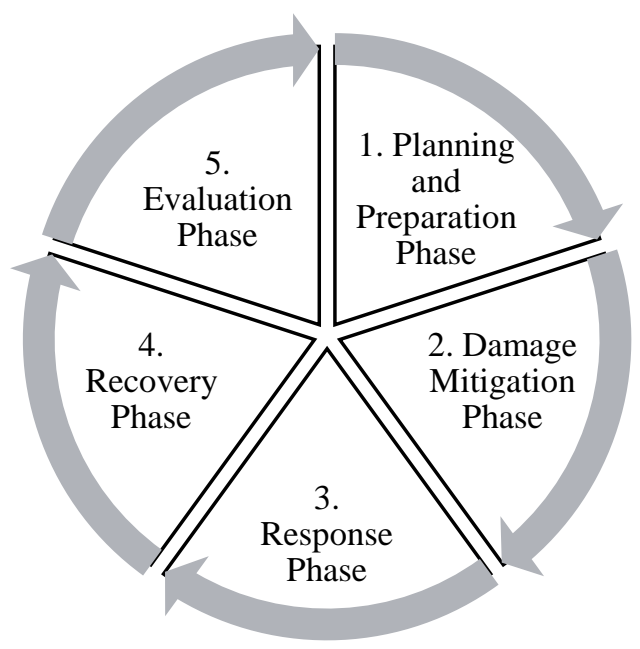

Figure 1 Disaster Management Cycle [8-10]

The effective factors are presented in achieving success at different phases of the cycle of disaster management. Since disaster management communicates with many areas, in terms of professional work in these areas, an area-based grouping is essential.

To improve the organizational effectiveness of management as a whole and to enable the entire management activity step by step, it is important to divide the disaster management process into meaningful elements and factors. It is necessary, however, to define success factors for disaster management to allow executives and decision-makers to concentrate on priority factors to enhance the process of disaster management [6]. Having considered these causes, several factors are key to the success of disaster management in various areas. While it is essential to consult with experts in various fields to evaluate these factors, identifying the factors in the literature called Critical Success Factors may guide to decide which topics regarding the combat against disasters should be used to prepare more dedicated studies. Therefore, in this study, previous research on this subject was examined to determine success factors in disaster management. The baseline studies were determined in this context, as shown in Table 1, and the main categories and factors determined by Ozceylan and Coskun [11] for a successful National Emergency Management Model were used to determine the study's route. After a literature review, three categories, environmental, legal, and operational, have been applied to these current categories. A change in the classification was made as socio-cultural and economic factors for the groups of cultural factors and socio-economic factors, based on other research shown in the literature review. With a comprehensive literature review, existing factors were expanded. The main factor groups were therefore gathered into 9 groups, as shown in Table 1.

Table 1 Literature Review Table of Main Factor Groups in Terms of Disaster Management Success

\begin{tabular}{|l|c|c|c|c|c|c|c|c|c|}
\hline Ozceylan and Coskun [11] & $\checkmark$ & $\checkmark$ & $\checkmark$ & & & $\checkmark$ & $\checkmark$ & & $\checkmark$ \\
\hline Chou and Wu [12] & $\checkmark$ & $\checkmark$ & $\checkmark$ & & & & & & $\checkmark$ \\
\hline Pathirage et al. [13] & $\checkmark$ & $\checkmark$ & $\checkmark$ & $\checkmark$ & $\checkmark$ & $\checkmark$ & $\checkmark$ & $\checkmark$ & \\
\hline Seneviratne et al. [14] & $\checkmark$ & $\checkmark$ & $\checkmark$ & $\checkmark$ & $\checkmark$ & $\checkmark$ & $\checkmark$ & $\checkmark$ & \\
\hline Seneviratne et al. [15] & $\checkmark$ & $\checkmark$ & $\checkmark$ & $\checkmark$ & $\checkmark$ & $\checkmark$ & $\checkmark$ & $\checkmark$ & \\
\hline $\begin{array}{l}\text { Ahmed, Ahmad, and } \\
\text { Zakaria [16] }\end{array}$ & & & $\checkmark$ & $\checkmark$ & & $\checkmark$ & & & \\
\hline
\end{tabular}


Cebeci et al.

A literature review was performed for each of the 9 areas listed, as can be seen in Table 1, because of a systematic literature review. As a result of the analysis, 240 success factors were uncovered. Similar factors were incorporated as a result of interviews with field experts, academic experts, and academics who are specialists in factors, and certain ones were omitted from success factors because of their repetition. Thus, the number of factors has been decreased to 122 . On the other hand, 122 factors were clustered as per the subjects to which they are relevant in nine areas and allocated to the corresponding 27 sub-factor groups. Sub-factor groups and factors are given in Table 2 with their corresponding academic references:

Table 2 Success Factors in Disaster Management

\begin{tabular}{|c|c|c|c|}
\hline $\begin{array}{l}\text { Main Factor } \\
\text { Group }\end{array}$ & Sub Factor Group & Factor & Source \\
\hline \multirow{8}{*}{ Economic } & \multirow{4}{*}{$\begin{array}{l}\text { Pre-Disaster } \\
\text { Preparation }\end{array}$} & Economic Planning & {$[6,11,13,14,15]$} \\
\hline & & $\begin{array}{l}\text { Distribution of Disaster Prevention } \\
\text { Resources }\end{array}$ & {$[12]$} \\
\hline & & Pre-Disaster Financial Instruments & {$[14,17]$} \\
\hline & & $\begin{array}{l}\text { Sufficient Financial Support for Disaster } \\
\text { Recovery Planning }\end{array}$ & [18] \\
\hline & \multirow{2}{*}{$\begin{array}{l}\text { Post-Disaster } \\
\text { Response }\end{array}$} & Restructuring Funds & {$[5,19]$} \\
\hline & & Investments for Mitigating Disaster Effect & {$[13]$} \\
\hline & \multirow{2}{*}{$\begin{array}{l}\text { Macro-Economic } \\
\text { Factors }\end{array}$} & Helpful Economic Environment & {$[5,20,21]$} \\
\hline & & Economic Growth / Development & {$[11-13]$} \\
\hline \multirow{11}{*}{ Environmental } & \multirow{7}{*}{$\begin{array}{c}\text { Environmental } \\
\text { Disaster Prevention } \\
\text { Activities }\end{array}$} & Use and Protection of Natural Barriers & {$[13,14,22]$} \\
\hline & & Using Man-Made Barriers & {$[13,14,23]$} \\
\hline & & Building and Urban Planning & {$[13,14]$} \\
\hline & & Land Use Planning & {$[13,22,24]$} \\
\hline & & Environmental Awareness and Education & {$[22]$} \\
\hline & & Addressing Environmental Issues & {$[22]$} \\
\hline & & Environmental Management Systems & {$[22]$} \\
\hline & \multirow{2}{*}{$\begin{array}{c}\text { Post-Disaster } \\
\text { Environmental } \\
\text { Responses } \\
\end{array}$} & Post-Disaster Waste Management & {$[13,23]$} \\
\hline & & Managing Chemical Hazard & {$[25]$} \\
\hline & \multirow[b]{2}{*}{ Post-Disaster Life } & Disaster Waste Recycling Systems & {$[13,23]$} \\
\hline & & $\begin{array}{l}\text { Criteria for environmental effects in } \\
\text { Restructuring Projects }\end{array}$ & {$[22]$} \\
\hline \multirow{12}{*}{ Socio-Cultural } & \multirow{4}{*}{$\begin{array}{l}\text { Individual Factors } \\
\text { (Qualifications and } \\
\text { Skills) }\end{array}$} & Individual Attitudes and Characteristics & [16] \\
\hline & & Specialty Skills & {$[25,26]$} \\
\hline & & Civil and Occupational Responsibilities & {$[13]$} \\
\hline & & Interpersonal Trust and Justice & {$[11,16]$} \\
\hline & \multirow{5}{*}{ Education } & Prevention and Response Training & {$[6,11,13,27,28,29]$} \\
\hline & & Post-Disaster Response Drills & {$[6,11,28,29]$} \\
\hline & & Rescue and Healthcare Professional Training & {$[6,18,27]$} \\
\hline & & $\begin{array}{l}\text { Educational Design (Education Quality, } \\
\text { Training Content) }\end{array}$ & {$[29]$} \\
\hline & & Continuous Education & [29] \\
\hline & \multirow{3}{*}{$\begin{array}{l}\text { Social Participation } \\
\text { and Association }\end{array}$} & Society's Participation & {$[5,11,12,30]$} \\
\hline & & Participation of Media Channels & {$[24,25,31]$} \\
\hline & & Participation of Military Units & {$[16,32,33]$} \\
\hline
\end{tabular}


Cebeci et al.

Table 2 Success Factors in Disaster Management (cont.)

\begin{tabular}{|c|c|c|c|}
\hline & & Private Sector Assistance & [12] \\
\hline & & Rehabilitation & [24] \\
\hline & & Participation of Civil Society Organizations & {$[16]$} \\
\hline & & Social Learning & [12] \\
\hline & & Disaster Culture & $\begin{array}{c}5,11,12,13,14 \\
19,24,25,32]\end{array}$ \\
\hline \multirow{23}{*}{ Technological } & \multirow{8}{*}{$\begin{array}{l}\text { Disaster Management } \\
\text { Support Systems }\end{array}$} & $\begin{array}{l}\text { Emergency Aid Support (Information) } \\
\text { System }\end{array}$ & {$[6,32,34]$} \\
\hline & & Projection and Early Warning Systems & $\begin{array}{l}{[6,11,13,14,15} \\
22,24,25,31,32]\end{array}$ \\
\hline & & Communication Systems & {$[13,15,24,32]$} \\
\hline & & Geographic Information Systems & {$[14,31]$} \\
\hline & & Post-Disaster Response System & {$[34,35]$} \\
\hline & & Information Management System & {$[13,19,25,36,37]$} \\
\hline & & Efficient Material Supply System & {$[19,28]$} \\
\hline & & Equipment Management System for Disaster & {$[24]$} \\
\hline & \multirow{3}{*}{$\begin{array}{c}\text { Effective } \\
\text { Communication } \\
\text { During and After } \\
\text { Disaster }\end{array}$} & Communication Technologies & [16] \\
\hline & & $\begin{array}{l}\text { Procedures for Effective Communication } \\
\text { Mechanism }\end{array}$ & {$[32,37]$} \\
\hline & & Technical Support Units & {$[24,25]$} \\
\hline & \multirow{7}{*}{$\begin{array}{l}\text { Information } \\
\text { Management }\end{array}$} & Sharing Information & $\begin{array}{c}{[11,16,24,31,37,38} \\
]\end{array}$ \\
\hline & & On-Time (Real-Time) Information & {$[34,39]$} \\
\hline & & Disaster Records with Time-Dimension & {$[12]$} \\
\hline & & Information Quality & {$[31,40]$} \\
\hline & & Information Centers & {$[11,18,27,41]$} \\
\hline & & Technology Use & {$[13,32]$} \\
\hline & & Trusted Sources of Information & {$[12]$} \\
\hline & \multirow{5}{*}{$\begin{array}{l}\text { Technological } \\
\text { Infrastructure }\end{array}$} & $\begin{array}{l}\text { Disaster Prevention Technology and } \\
\text { Infrastructure }\end{array}$ & {$[11,12]$} \\
\hline & & Communication Network and Infrastructure & {$[11,24,31]$} \\
\hline & & Information Update Mechanism & [42] \\
\hline & & Structural Measures & {$[15,43]$} \\
\hline & & Logistics Technology & {$[6,28]$} \\
\hline \multirow{7}{*}{ Operational } & \multirow{7}{*}{$\begin{array}{l}\text { Pre-Disaster Planning } \\
\text { Activities }\end{array}$} & Disaster Management Model & {$[42]$} \\
\hline & & Creating a Disaster and Emergency Plan & $\begin{array}{c}{[13,18,19,25,27,32} \\
]\end{array}$ \\
\hline & & Quality Control Activities & [19] \\
\hline & & Statistics of Previous Disasters and Analyzes & {$[2,44,45]$} \\
\hline & & Execution of Planning Documentation & {$[27]$} \\
\hline & & $\begin{array}{l}\text { Continuous Assessment and Improvement of } \\
\text { Disaster Management System }\end{array}$ & {$[6,19,32]$} \\
\hline & & Operational Consistency / Harmony & [25] \\
\hline
\end{tabular}


Cebeci et al.

Table 2 Success Factors in Disaster Management (cont.)

\begin{tabular}{|c|c|c|c|}
\hline & & $\begin{array}{l}\text { Access and Evacuation Channels for People } \\
\text { Affected by Disaster }\end{array}$ & {$[5,24]$} \\
\hline & Systems and & Time Management in Crisis Time & [19] \\
\hline & & $\begin{array}{l}\text { Taking Precautions of Preventive Health } \\
\text { Measures }\end{array}$ & {$[24,25]$} \\
\hline & & Assessment of Damage & {$[5,13]$} \\
\hline & Post-Disaster & Prioritizing Activities of Improvement & {$[27]$} \\
\hline & Recovery (Rescue) & Search and Rescue Operations & [25] \\
\hline & Operations & Assessing Disaster Effect & {$[24,25]$} \\
\hline & & Restructuring Activities & {$[25]$} \\
\hline & Logistics Activities & Logistics Planning and Management & {$[6,11,14,32,37]$} \\
\hline & $\begin{array}{l}\text { Before, During, and } \\
\text { After Disaster }\end{array}$ & Resource Planning and Management & $\begin{array}{c}{[12,24,30,32,35,37} \\
, 46]\end{array}$ \\
\hline & & Security of Rescue Equipment & {$[6,28]$} \\
\hline & & Organizational Culture & {$[11,16,29,35]$} \\
\hline & & Transparency and Accountability & {$[5,19,35]$} \\
\hline & & Organizational Design & [11] \\
\hline & & Corporate Arrangement & {$[13,32,37]$} \\
\hline & Organizational & Centralized Decision-Making Structure & {$[11]$} \\
\hline & Structure & Executive Support & {$[11,16,18,27]$} \\
\hline & & Enterprise Integration & {$[14]$} \\
\hline & & Unity of Purpose and Political Goals & {$[27,32,37]$} \\
\hline & & Organizational Agility & [35] \\
\hline & & Response Time & [6] \\
\hline & & Precise Job Description and Roles & {$[11,42]$} \\
\hline & & $\begin{array}{l}\text { Inter-Organizational and External } \\
\text { Communication }\end{array}$ & {$[11,13]$} \\
\hline Organizational & $\begin{array}{c}\text { Inter-Organizational } \\
\text { Collaboration and } \\
\text { Participation }\end{array}$ & Coordination and Collaboration & $\begin{array}{c}{[5,11,12,19,24,25,} \\
28, \\
31,32,35,36,37,42, \\
47]\end{array}$ \\
\hline & & $\begin{array}{l}\text { Degree of Involvement in the Process of } \\
\text { Decision Making }\end{array}$ & {$[11,18,27]$} \\
\hline & & Developing the Master Plan & [13] \\
\hline & Corporate Disaster & Disaster Management System & [25] \\
\hline & Management Plan & Disaster Management Strategy and Plan & $\begin{array}{c}{[6,11,28,31,32,35,} \\
42]\end{array}$ \\
\hline & & Planning the Rescue Needs & {$[6,28]$} \\
\hline & & Taking Individual and Institutional Initiative & {$[30]$} \\
\hline & Individual & Leadership & {$[11,14]$} \\
\hline & Competencies & Teamwork & {$[11,19]$} \\
\hline & & $\begin{array}{l}\text { Managers Staff and Team Member } \\
\text { Competencies }\end{array}$ & {$[13,19,32,37]$} \\
\hline Political & $\begin{array}{l}\text { Communication and } \\
\text { Information }\end{array}$ & $\begin{array}{l}\text { Quality of Government Sharing of } \\
\text { Information }\end{array}$ & {$[36]$} \\
\hline & Management & Public Advice and Advisory Services & [25] \\
\hline
\end{tabular}


Cebeci et al.

Table 2 Success Factors in Disaster Management (cont.)

\begin{tabular}{|c|c|c|c|}
\hline & & $\begin{array}{l}\text { Network with NGOs and International } \\
\text { Organizations }\end{array}$ & {$[12,34$} \\
\hline & & Cooperation with Other Countries & [42] \\
\hline & \multirow{4}{*}{ Operational Factors } & Restructuring Support & {$[13,47]$} \\
\hline & & $\begin{array}{l}\text { Including Disaster Management Contents in } \\
\text { National Education Curriculum }\end{array}$ & {$[13$} \\
\hline & & National Disaster Management Policy & [25] \\
\hline & & Health, Safety and Security Management & [19] \\
\hline \multirow{7}{*}{ Legal } & \multirow{5}{*}{$\begin{array}{l}\text { Restrictive Legal } \\
\text { Regulations }\end{array}$} & Enactments and Laws & [11] \\
\hline & & Terms of References and Regulations & {$[6,11,28]$} \\
\hline & & Production Regulations & [13] \\
\hline & & Local Regulations & {$[11]$} \\
\hline & & Environmental Rules and Standards & [22] \\
\hline & $\begin{array}{l}\text { Factors Related to the } \\
\text { Implementation of }\end{array}$ & $\begin{array}{l}\text { Consideration of Social Factors When } \\
\text { Making Laws }\end{array}$ & {$[14]$} \\
\hline & Laws & Continuous Legal Regulations Update & [14] \\
\hline & & Geographical Risks & {$[11,12]$} \\
\hline & Pre-Disaster (Related & Political Risks & {$[11,19]$} \\
\hline & to Disaster) Risks & Technological Risks & {$[11$} \\
\hline & & Evacuation Risk & {$[48,49]$} \\
\hline Risk & & Risk Evaluation & $\begin{array}{c}{[12,13,14,18,22,25} \\
, 27] \\
\end{array}$ \\
\hline & Risk Factors Related & Evaluation of Potential Vulnerability & {$[14,24,25]$} \\
\hline & $\begin{array}{l}\text { to Disaster } \\
\text { Management }\end{array}$ & $\begin{array}{l}\text { Experience Level Concerning Different } \\
\text { Types of } \\
\text { Disasters }\end{array}$ & {$[11]$} \\
\hline & & Infrastructure & [11] \\
\hline
\end{tabular}

While the literature review is outlined in Table 2, it also describes a hierarchical left-to-right model consisting of 9 main factor groups, 27 sub-factor groups, and 122 factors. For instance, since certain factors are formed as per the phases of disaster management, as a conclusion of the analysis performed for the main economic factor group, a grouping was therefore developed as Pre-Disaster Preparation and Post-Disaster Response, while the Supportive Economic Environment and Economic Growth / Development factors are grouped as Macroeconomic factors because they will provide large-scale precautions and response. Groupings were created for the other 8 main factor categories because of the shared features of the factors. A method for managing such an integrated structure was necessary due to the hierarchical structure of a table obtained in this way and a high number of factors. In this context, an integrated approach was applied to collect data for different layers of the hierarchy from various expert groups. In the next part, the model is illustrated.

\section{Method}

Critical Success Factors (CSF) are described as a specific number of areas that provide the company with a good competitive result if the effects are satisfactory for companies, and they are a few main areas that have to be properly implemented for the businesses to grow [50]. It is necessary for the short and long-term success of a project, organization, or initiative to acknowledge or assess the CSF in a management system [51]. To guarantee the success of a management process such as disaster 
Cebeci et al.

management, which involves multiple disciplines within its body, by specifying significant levels to different aspects, it is important to recognize the critical aspects and to conduct the necessary activities by concentrating on these factors. However, there are studies carried out to determine critical success factors through a limited number of factors [6] even they focus on certain areas of disaster management [3], certain stages $[4,5]$ or directly on disaster management. It can also be stated that it is of crucial importance to evaluate critical success factors in the domain of disaster management. In this study, the model in figure 2 was established to manage the hierarchical structure formed by many factors from the perspective of different expert groups.

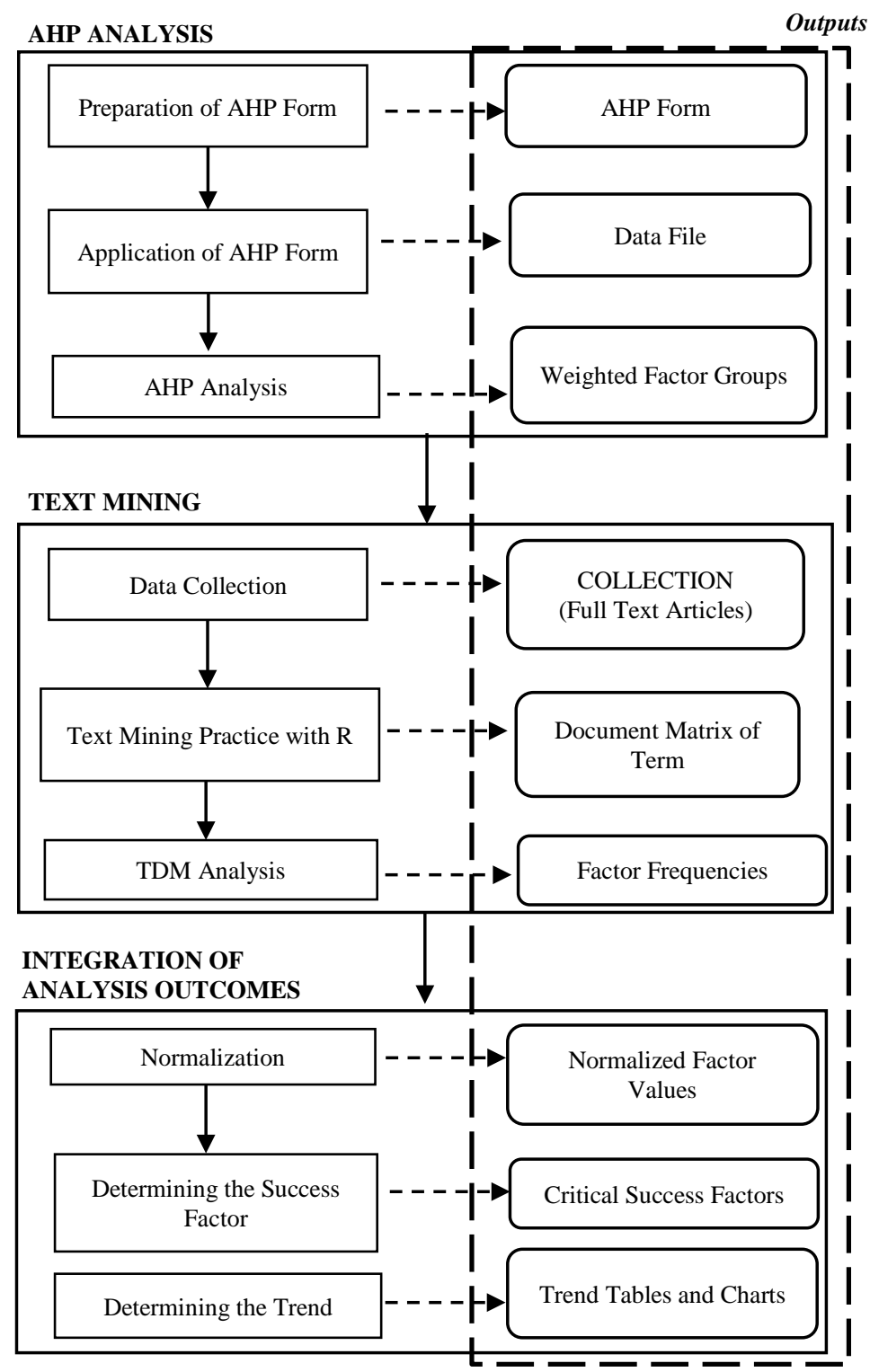

Figure 2 Critical Success Factor Model

It was determined to use the AHP method to collect the views of field experts on a successful disaster management system. The AHP approach helps decision-makers to analyze perceptions, senses, decisions, and experiences that impact their choices by comparing and evaluating them [52]. Thus, as it has a resolution structure that contains objective and subjective components, relative to many decisionmaking methods, it can be viewed as a more realistic solution approach [53]. Since these too many binary combinations that arise in the comparison of factors which are the lowest layer of the hierarchy will take too much time for the experts, they cannot make gathering data feasible. Therefore, this method could not be utilized for factors. As an alternative technique, the text mining method was included in the study in the evaluation of 122 factors, to capture and evaluate data relating to academic studies after 
Cebeci et al.

taking into account its capacity of including views of academics in the model. Thus, a method model was proposed by multiplying the normalized values of layers from top to bottom to reflect the evaluation of the last layer of academic experts and also the first two layers of field experts. Furthermore, by reflecting the data collected from academic studies up to the hierarchy, it was attempted to specify the areas and factors on which the studies concentrate on each layer of the hierarchy by years.

\subsection{AHP Analysis}

In this study, the AHP approach, which has a solution framework that includes objective and subjective aspects, was selected to evaluate the personal opinions of individuals who are accredited as disaster management experts. In this sense, by granting their significance, AHP allows for binary comparison of factors and prioritization. To compare the main factor groups with each other and the sub-factor groups among themselves within the main factor group to which they belong, the AHP form was applied to the experts in a structure designed in such a way that the main factor groups represent the first level of the hierarchy, the sub-factor groups form the second level of the hierarchy, and lastly, the factors constitute the third level of the hierarchy. The factors in the third level of the hierarchy were not included in the AHP application since too many binary comparison combinations they must make the application harder. Thus, the hierarchical structure of the AHP application consisting of the first two levels of the hierarchy can be seen in Figure 3:

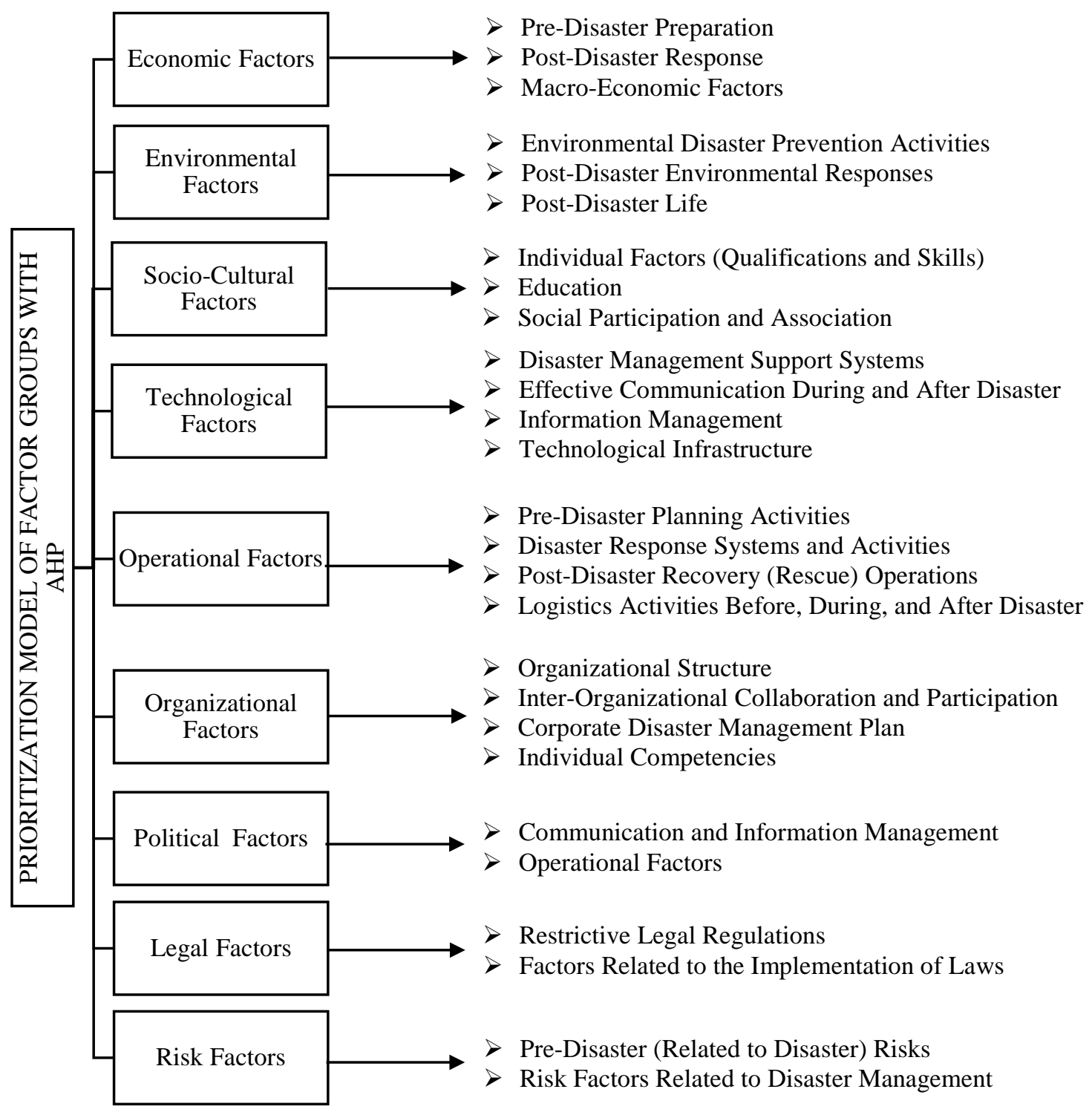

Figure 3 Prioritization Model of Factor Groups with AHP 
Cebeci et al.

To prioritize the groups seen in the hierarchy model from 1 to 9 in pairs, a 9-point AHP form was developed. A total of 20 individuals, including civil defense experts employed in different provinces and participating in the training program organized by the Ministry of Agriculture and Forestry of the Republic of Turkey in Antalya, disaster management experts from Ankara, Sakarya, and Yalova, and an academic with a Ph.D. in earthquake engineering, were administered to this form. With the data obtained, matrices were created, and the weights of the main factor groups derived from the solution of these matrices and the weights of the sub-factor groups belonging to these main factor groups were multiplied downwards. The real weights of the sub-factor groups were thus calculated and in other main factor groups, they were contrasted with the sub-factor groups.

\subsection{Text Mining}

The high number of disaster management studies and the fact that a total of 122 successful factors for disaster management will be analyzed from an academic perspective required the process to become semi-automated. For this purpose, in the second phase of the method model, the method of text mining, which can systematically analyze documents involving large numbers of unstructured data collected as a result of a comprehensive literature review to automate the process, was chosen. In this sense, the search for the "Sciencedirect" academic publication database in 2017 using the keyword of "Disaster Management" was performed to access academic publications in the field of disaster management. 773 papers published between 2000 and 2016 were included in the study, as a result of the searching publications in the field.

To make them ready for the method, the articles were transformed into plain text (TXT) files, then the collections were cleaned with pre-processing and the quality of the data was improved. The size of the data set was decreased by removing low-frequency data with a repetition frequency of less than $1 \%$ from the study to handle the large matrix consisting of 160508 rows. Thus, the number of rows has reduced to 13332. A single word assessment would not be adequate due to the long texts of certain factors in disaster management, so phrases up to 7 words were included in the Term Document Matrix (TDM) with the N-Gram technique if they exceed the repetition frequency. A single TDM matrix consisting of 34043 rows and 786 columns was generated by merging the 7 TDMs provided.

It was considered that converting 13332 words or word groups to 122 factors with an automated topical modeling approach such as machine learning gave ineffective results, given the similar expressions and intersects of disaster management factors. Therefore, this converting procedure was conducted with the Excel search function and with binary cross-validation manual coding.

\subsection{Integration of Analyses}

The research integration was accomplished by vertically multiplying from top to bottom the weighted values obtained by the AHP method and the normalization results calculated by the text mining method in the hierarchy. To grasp the general structure, as shown in Figure 4, the CSS calculation model that will bring us to the aim of the research has been visualized. The first hierarchical level AHP weight value in CSF calculation is shown as $\mathrm{W}_{\mathrm{i}}(\mathrm{i}=1,9)$ ), the second hierarchical level AHP weight value is shown as $W_{i j}(i=1,9),(j=1,4)$ and lastly, the third hierarchical level Text Mining weight value is shown as $\mathrm{W}_{\mathrm{ijz}}(\mathrm{i}=1,9),(\mathrm{j}=1,4),(\mathrm{z}=1,11)$. To calculate CSS, weighted values of Main Factor Groups and SubFactor Groups were first obtained. For text mining, which gives the values of the factors, by the Linear Normalization method, firstly the data is normalized. At this point, the frequencies derived concerning the number of each factor mentioned in all articles were divided into the total number of articles (773) and the normalization was carried out by multiplying these values by 100 to prevent them from being too small in the triple scalar product and to increase their value to 0-1. As a consequence, integrated weights of each factor (122) were obtained by multiplying the AHP weight values of the main factor groups vertically from top to bottom with the AHP weight values of the sub-factor groups of these main factor groups and the normalization values obtained by text mining analysis of these sub-factor groups. These integrated weights form the Critical Success Score (CSS) of these factors. 


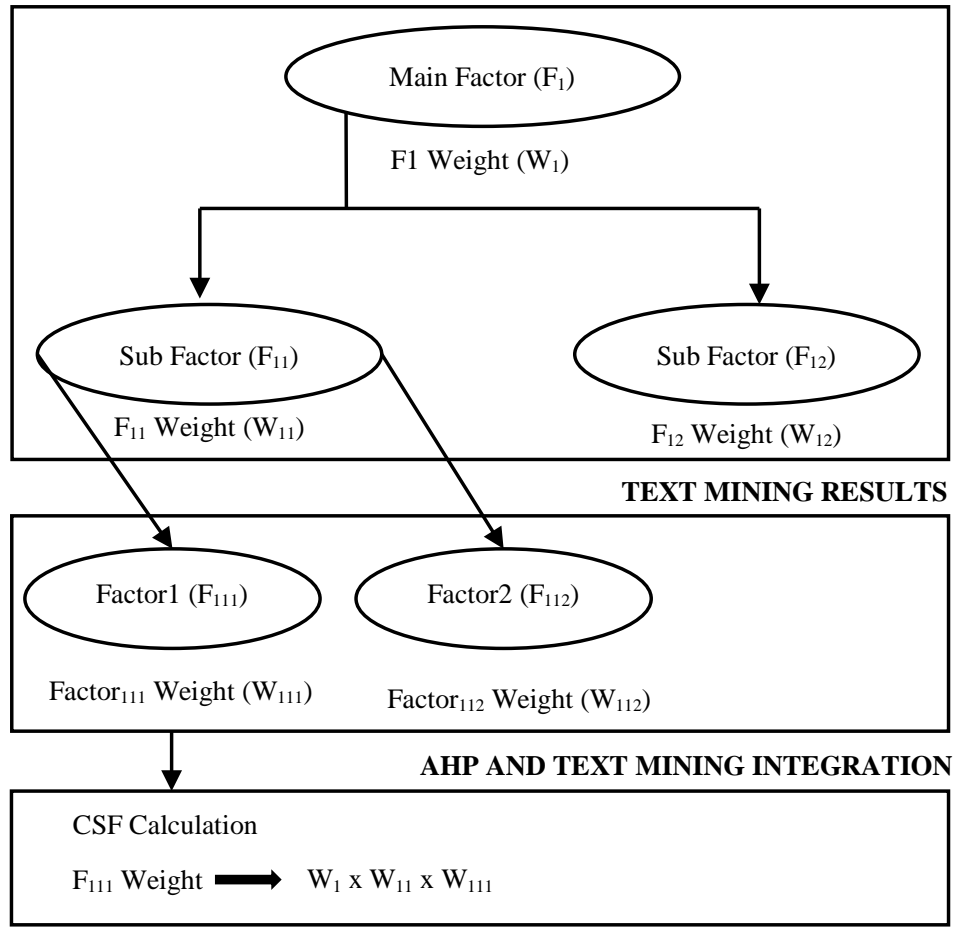

Figure 4 Critical Success Score Calculation Model

Since raw text files are recorded with year prefixes, as stated in text mining analyses, therefore the data provides an opportunity to show which areas the emphasis has shifted to regarding the success of disaster management. The results of "Trend Analysis" are also provided at the last stage of the study based on this situation. The values of linear regression slopes were analyzed in trend analysis by considering the values that state in how many articles each factor was listed.

\section{Findings}

The AHP method and the text mining method will be presented separately before the results that are obtained by combining these two methods to evaluate the views of operational and academic experts separately. On the other hand, integrated results together include the views of operational and academic experts in assessing the critical success factors that are the aim of the study. Although there are several studies in this field, including the opinions of operational experts is of particular importance in terms of successful disaster management in Turkey.

\subsection{AHP Analysis Findings}

By evaluating data obtained from the views of operational experts in disaster management, a prioritization was established among 9 main factor groups. This prioritization is shown in Table 3:

Table 3 Main Factor Weights

\begin{tabular}{|l|c|}
\hline \multicolumn{1}{|c|}{ Main Factors } & Weights \\
\hline Legal Factors & 0.19 \\
\hline Risk Factors & 0.16 \\
\hline Socio-Cultural Factors & 0.15 \\
\hline Political Factors & 0.14 \\
\hline Organizational Factors & 0.12 \\
\hline Operational Factors & 0.09 \\
\hline Technological Factors & 0.07 \\
\hline Environmental Factors & 0.05 \\
\hline Economic Factors & 0.04 \\
\hline
\end{tabular}


Cebeci et al.

The weight averages determined for the lower level of the AHP hierarchical model are given in Table 4 together with their consistency rates, including the weight values of the sub-factor groups based on the main factor group and the normalized weight values for comparison with other sub-factor groups.

Table 4 Normalized Weight Values for Sub-Factor Groups

\begin{tabular}{|c|c|c|c|c|}
\hline \multirow[b]{2}{*}{$\begin{array}{l}\text { Main Factor } \\
\text { Groups }\end{array}$} & \multirow[b]{2}{*}{ Sub Factor Groups } & \multicolumn{3}{|c|}{ Factor Weights } \\
\hline & & $\begin{array}{l}\text { Main } \\
\text { Factor }\end{array}$ & $\begin{array}{l}\text { Sub Factor } \\
\text { Group }\end{array}$ & $\begin{array}{c}\text { Normalized } \\
\text { Factor }\end{array}$ \\
\hline \multirow{3}{*}{$\begin{array}{l}\text { Economic } \\
\text { Factors } \\
\mathrm{CR}=0,01\end{array}$} & Pre-Disaster Preparation & \multirow{3}{*}{0.04} & 0.69 & 0.028 \\
\hline & Post-Disaster Response & & 0.11 & 0.005 \\
\hline & Macro-Economic Factors & & 0.20 & 0.008 \\
\hline \multirow{3}{*}{$\begin{array}{l}\text { Environmental } \\
\text { Factors } \\
\text { CR }=0,01\end{array}$} & Environmental Disaster Prevention Activities & \multirow{3}{*}{0.05} & 0.74 & 0.039 \\
\hline & Environmental Response After Disasters & & 0.13 & 0.007 \\
\hline & Post-Disaster Life & & 0.14 & 0.007 \\
\hline \multirow{3}{*}{$\begin{array}{l}\text { Socio-Cultural } \\
\text { Factors } \\
\text { CR }=0,02\end{array}$} & Individual Factors (Qualifications and Skills) & \multirow{3}{*}{0.15} & 0.11 & 0.015 \\
\hline & Education & & 0.50 & 0.074 \\
\hline & Social Participation and Association & & 0.39 & 0.058 \\
\hline \multirow{4}{*}{$\begin{array}{l}\text { Technological } \\
\text { Factors } \\
\text { CR }=0,07\end{array}$} & Disaster Management Support Systems & \multirow{4}{*}{0.07} & 0.30 & 0.02 \\
\hline & $\begin{array}{l}\text { Effective Communication During and After } \\
\text { Disaster }\end{array}$ & & 0.19 & 0.013 \\
\hline & Information Management & & 0.22 & 0.015 \\
\hline & Technological Infrastructure & & 0.30 & 0.02 \\
\hline \multirow{4}{*}{$\begin{array}{l}\text { Operational } \\
\text { Factors } \\
\text { CR }=0,07\end{array}$} & Pre-Disaster Planning Activities & \multirow{4}{*}{0.09} & 0.52 & 0.045 \\
\hline & Disaster Response Systems and Activities & & 0.19 & 0.016 \\
\hline & Post-Disaster Recovery (Rescue) Operations & & 0.16 & 0.013 \\
\hline & $\begin{array}{l}\text { Logistics Activities Before, During, and After } \\
\text { Disaster }\end{array}$ & & 0.13 & 0.012 \\
\hline \multirow{4}{*}{$\begin{array}{l}\text { Organizational } \\
\text { Factors } \\
\mathrm{CR}=0,01\end{array}$} & Organizational Structure & \multirow{4}{*}{0.12} & 0.19 & 0.023 \\
\hline & $\begin{array}{l}\text { Inter-Organizational Collaboration and } \\
\text { Participation }\end{array}$ & & 0.32 & 0.037 \\
\hline & Corporate Disaster Management Plan & & 0.34 & 0.04 \\
\hline & Individual Competencies & & 0.14 & 0.017 \\
\hline \multirow{2}{*}{$\begin{array}{l}\text { Political Factors } \\
\text { CR }=0\end{array}$} & Communication and Information Management & \multirow{2}{*}{0.14} & 0.45 & 0.064 \\
\hline & Operational Factors & & 0.55 & 0.077 \\
\hline \multirow{2}{*}{$\begin{array}{l}\text { Legal Factors } \\
\text { CR }=0\end{array}$} & Restrictive Legal Regulations & \multirow[b]{2}{*}{0.19} & 0.19 & 0.035 \\
\hline & $\begin{array}{l}\text { Factors Related to the Implementation of } \\
\text { Laws }\end{array}$ & & 0.81 & 0.153 \\
\hline \multirow{2}{*}{$\begin{array}{l}\text { Risk Factors } \\
\mathrm{CR}=0\end{array}$} & Pre-Disaster (Related to Disaster) Risks & \multirow{2}{*}{0.16} & 0.44 & 0.071 \\
\hline & Risk Factors Related to Disaster Management & & 0.56 & 0.089 \\
\hline
\end{tabular}

As the consistency ratio (CR) of all matrices belonging to the sub-factors is less than 0.1 , it is understood that the evaluations made for each group by the participants are consistent. When the sub-factor groups in Table 4 are evaluated, especially the "Factors Related to the Implementation of Laws" sub-factor group along with the "Pre-Disaster Preparation", "Environmental Disaster Prevention Activities", "PreDisaster Planning Activities" sub-factor groups have come to the fore due to their important weight values in the main factor group they belong to. This case demonstrates the importance of legal factors under main factor groups within the scope of disaster management studies in Turkey. However, the weight values of the other three sub-factor groups suggest that, relative to post-disaster studies, the factors related to the reduction of the impact of disasters prior to the disaster should be given more significance, in line with the views of the people work in this field.

The values in the right column of the table are obtained by multiplying the weights of the main factor groups by the weights of the sub-factor groups of those main factor groups so that the sub-factor groups can be compared with those of the sub-factor groups of the other main factor groups. When considering the values, the group of "Factors Related to the Implementation of Laws" was concluded as the most important sub-factor group with a weighted average of 0.153. It has been determined that there is a lack of direct law enforcement in Turkey on the grounds of this group, which is considered to be the most 
important compared to all other sub-factors, and it can be concluded that the focus should be on the implementation of laws. Besides, both groups have come to the fore with significant values in the Risk Main Factor Group, and the importance of risk management is also recognized from the experts' perspective. This shows that significance should be given to studies within the framework of risk management. Again, the 'Operational Factors', 'Education', 'Communication and Information Management' sub-factor groups were considered essential and these observations revealed the legal, risk, and political main factor groups based on sub-factor groups.

\subsection{Text Mining Analysis Findings}

Over 773 articles published between 2000 and 2016 text mining analysis was performed and revealed in how many articles each factor was mentioned. Frequencies belonging to sub-factor groups and main factor groups were established via the results obtained as per the factors. In this context, when assessed in terms of factors, the 20 factors which were the most mentioned ones by academic studies are classified in Table 5 according to the results of the text mining analysis.

Table 5 Number of Articles That Were Mentioned the Factors

\begin{tabular}{|c|c|c|c|c|c|}
\hline Ordering & Main FG & Sub Factor Group & Factors & $\begin{array}{l}\text { Number } \\
\text { of } \\
\text { Articles }\end{array}$ & $\begin{array}{c}\text { Percentage } \\
\text { (\%) }\end{array}$ \\
\hline 1 & Legal & $\begin{array}{l}\text { Restrictive Legal } \\
\text { Regulations }\end{array}$ & $\begin{array}{l}\text { Terms of References and } \\
\text { Regulations }\end{array}$ & 258 & 33.38 \\
\hline 2 & Legal & $\begin{array}{l}\text { Restrictive Legal } \\
\text { Regulations }\end{array}$ & Enactments and Laws & 229 & 29.62 \\
\hline 3 & Technological & $\begin{array}{l}\text { Disaster Management } \\
\text { Support Systems }\end{array}$ & $\begin{array}{l}\text { Information Management } \\
\text { System }\end{array}$ & 206 & 26.65 \\
\hline 4 & Operational & $\begin{array}{l}\text { Pre-Disaster Planning } \\
\text { Activities }\end{array}$ & $\begin{array}{l}\text { Creating a Disaster and } \\
\text { Emergency Plan }\end{array}$ & 197 & 25.49 \\
\hline 5 & Technological & $\begin{array}{l}\text { Information } \\
\text { Management }\end{array}$ & Sharing Information & 193 & 24.97 \\
\hline 6 & Environmental & $\begin{array}{l}\text { Environmental Disaster } \\
\text { Prevention Activities }\end{array}$ & \begin{tabular}{lr}
\multicolumn{2}{l}{ Use and Protection of } \\
Natural $\quad$ Barriers
\end{tabular} & 180 & 23.29 \\
\hline 7 & Organizational & $\begin{array}{l}\text { Corporate Disaster } \\
\text { Management Plan }\end{array}$ & $\begin{array}{l}\text { Disaster Management } \\
\text { Strategy and Plan }\end{array}$ & 178 & 23.03 \\
\hline 8 & Technological & $\begin{array}{l}\text { Disaster Management } \\
\text { Support Systems }\end{array}$ & \begin{tabular}{ll}
\multicolumn{2}{l}{ Projection and Early } \\
Warning & Systems
\end{tabular} & 173 & 22.38 \\
\hline 9 & Organizational & $\begin{array}{l}\text { Inter-Organizational } \\
\text { Collaboration and } \\
\text { Participation }\end{array}$ & $\begin{array}{l}\text { Coordination and } \\
\text { Collaboration }\end{array}$ & 172 & 22.25 \\
\hline 10 & Technological & $\begin{array}{l}\text { Disaster Management } \\
\text { Support Systems }\end{array}$ & $\begin{array}{l}\text { Emergency Aid Support } \\
\text { (Information) System }\end{array}$ & 158 & 20.44 \\
\hline 11 & Operational & $\begin{array}{l}\text { Logistics Act. Before, } \\
\text { During, and After } \\
\text { Disaster }\end{array}$ & $\begin{array}{l}\text { Resource Planning and } \\
\text { Management }\end{array}$ & 151 & 19.53 \\
\hline 12 & Risk & $\begin{array}{l}\text { Risk Factors Related to } \\
\text { Disaster Management }\end{array}$ & Risk Evaluation & 150 & 19.40 \\
\hline 13 & Economic & $\begin{array}{l}\text { Pre-Disaster } \\
\text { Preparation }\end{array}$ & $\begin{array}{l}\text { Pre-Disaster Financial } \\
\text { Instruments }\end{array}$ & 149 & 19.28 \\
\hline 14 & Technological & $\begin{array}{l}\text { Information } \\
\text { Management }\end{array}$ & $\begin{array}{l}\text { Communication Content } \\
\text { (Information) Quality }\end{array}$ & 142 & 18.37 \\
\hline 15 & Legal & $\begin{array}{l}\text { Restrictive Legal } \\
\text { Regulations }\end{array}$ & Local Regulations & 131 & 16.95 \\
\hline 16 & Operational & $\begin{array}{l}\text { Pre-Disaster Planning } \\
\text { Activities }\end{array}$ & $\begin{array}{l}\text { Statistics and Analysis of } \\
\text { Previous Disasters }\end{array}$ & 128 & 16.56 \\
\hline
\end{tabular}


Cebeci et al.

Table 5 Number of Articles That Were Mentioned the Factors (cont.)

\begin{tabular}{|c|l|l|l|c|c|}
\hline $\mathbf{1 7}$ & Technological & $\begin{array}{l}\text { Technological } \\
\text { Infrastructure }\end{array}$ & Logistics Technology & 114 & 14.75 \\
\hline $\mathbf{1 8}$ & Operational & $\begin{array}{l}\text { Logistics Act. Before, } \\
\text { During, and After } \\
\text { Disaster }\end{array}$ & $\begin{array}{l}\text { Logistics Planning and } \\
\text { Management }\end{array}$ & 114 & 14.75 \\
\hline $\mathbf{1 9}$ & Organizational & $\begin{array}{l}\text { Individual } \\
\text { Competencies }\end{array}$ & Leadership & 110 & 14.23 \\
\hline $\mathbf{2 0}$ & Operational & $\begin{array}{l}\text { Post-Disaster Recovery } \\
\text { (Rescue) Operations }\end{array}$ & Assessing Disaster Effect & 108 & 13.97 \\
\hline
\end{tabular}

Taking Table 5 into account, it is seen that the first 20 factors have so many technical factors. In line with the views of academic experts, the fact that there are 5 factors of operational factors highlights the importance of technology and operational studies in general. In this context, it can be concluded that, in practice, attention should be paid to these two areas. The number of main factor groups and sub-factor groups articles and rates generated by the number of articles considered on a factor basis are shown in Table 6 (Since the factor belonging to more than one group is mentioned in the same article, the total number is seen more than 773 articles.).

Table 6 Number of Publications Mentioning the Main Factor Groups and Sub-Factor Groups

\begin{tabular}{|c|c|c|c|}
\hline Main Factors & Sub Factor Groups & $\begin{array}{l}\text { Number } \\
\text { of Articles }\end{array}$ & $\begin{array}{l}\text { Percentage } \\
(\%)\end{array}$ \\
\hline $\begin{array}{l}\text { Economic Factors } \\
269(\% 34.80)\end{array}$ & $\begin{array}{l}\text { Pre-Disaster Preparation } \\
\text { Post-Disaster Response } \\
\text { Macro-Economic Factors }\end{array}$ & $\begin{array}{c}225 \\
30 \\
85\end{array}$ & $\begin{array}{c}29.11 \\
3.88 \\
11\end{array}$ \\
\hline $\begin{array}{l}\text { Environmental } \\
\text { Factors } \\
293(\% 37.90)\end{array}$ & $\begin{array}{l}\text { Environmental Disaster Prevention Activities } \\
\text { Environmental Response After Disasters } \\
\text { Post-Disaster Life }\end{array}$ & $\begin{array}{c}253 \\
78 \\
33\end{array}$ & $\begin{array}{c}32.73 \\
10.09 \\
4.27\end{array}$ \\
\hline $\begin{array}{l}\text { Socio-Cultural } \\
\text { Factors } \\
317(\% 41.01)\end{array}$ & $\begin{array}{l}\text { Individual Factors (Qualifications and Skills) } \\
\text { Education } \\
\text { Social Participation and Association }\end{array}$ & $\begin{array}{c}70 \\
168 \\
174\end{array}$ & $\begin{array}{l}9.06 \\
21.73 \\
22.51\end{array}$ \\
\hline $\begin{array}{l}\text { Technological } \\
\text { Factors } \\
587(\% 75.94)\end{array}$ & $\begin{array}{l}\text { Disaster Management Support Systems } \\
\text { Effective Communication During and After } \\
\text { Disaster } \\
\text { Information Management } \\
\text { Technological Infrastructure }\end{array}$ & $\begin{array}{l}455 \\
165 \\
356 \\
235\end{array}$ & $\begin{array}{l}58.86 \\
21.35 \\
46.05 \\
30.40\end{array}$ \\
\hline $\begin{array}{l}\text { Operational Factors } \\
538(\% 69.60)\end{array}$ & $\begin{array}{l}\text { Pre-Disaster Planning Activities } \\
\text { Disaster Response Systems and Activities } \\
\text { Post-Disaster Recovery (Rescue) Operations } \\
\text { Logistics Activities Before, During, and After } \\
\text { Disaster }\end{array}$ & $\begin{array}{l}368 \\
125 \\
219 \\
233\end{array}$ & $\begin{array}{l}47.61 \\
16.17 \\
28.33 \\
30.14\end{array}$ \\
\hline $\begin{array}{l}\text { Organizational } \\
\text { Factors } \\
423(\% 54.72)\end{array}$ & $\begin{array}{l}\text { Organizational Structure } \\
\text { Inter-Organizational Collaboration and } \\
\text { Participation } \\
\text { Corporate Disaster Management Plan } \\
\text { Individual Competencies }\end{array}$ & $\begin{array}{l}215 \\
216 \\
233 \\
180\end{array}$ & $\begin{array}{l}27.81 \\
27.94 \\
30.14 \\
23.29\end{array}$ \\
\hline $\begin{array}{l}\text { Political Factors } \\
237 \text { (\%30.66) }\end{array}$ & $\begin{array}{l}\text { Communication and Information Management } \\
\text { Operational Factors }\end{array}$ & $\begin{array}{l}158 \\
131\end{array}$ & $\begin{array}{l}20.44 \\
16.95\end{array}$ \\
\hline $\begin{array}{l}\text { Legal Factors } \\
439(\% 56.79)\end{array}$ & $\begin{array}{l}\text { Restrictive Legal Regulations } \\
\text { Factors Related to the Implementation of Laws }\end{array}$ & $\begin{array}{c}439 \\
7\end{array}$ & $\begin{array}{c}56.79 \\
0.91\end{array}$ \\
\hline $\begin{array}{l}\text { Risk Factors } \\
233(30.14)\end{array}$ & $\begin{array}{l}\text { Pre-Disaster (Related to Disaster) Risks } \\
\text { Risk Factors Related to Disaster Management }\end{array}$ & $\begin{array}{c}84 \\
207\end{array}$ & $\begin{array}{l}10.87 \\
26.78\end{array}$ \\
\hline
\end{tabular}


The factors belonging to the sub-factor groups of "Disaster Management Support Systems" and "Restrictive Legal Regulations" are mostly mentioned ones in academic publications, and the factors of "Pre-Disaster Planning Activities" were also mentioned in a more significant ratio compared to other factor groups. Also, the ratio of $46.05 \%$ received by the "Information Management" sub-factor group revealed the importance of the "Disaster Management Support Systems" sub-factor group and the technological factors in academic studies based on the sub-factor group. The frequency values of the factors and the number of articles were also estimated, as well as the percentage values of the main factor groups, and these values can be seen in Table 6 .

Technological factors were listed in the highest number of publications, according to the frequency values in Table 6. It can be seen in this sense that today's technical advances are or should be expressed in the domain of disaster management. Within the framework of academic studies, operational factors that can be regarded as tangible indicators of disaster management have been given prime attention. The two main factor groups that fell behind based on AHP results, should also be taking into consideration by disaster management actors of Turkey based on academic studies. This comparison is also visualized in Figure 5:

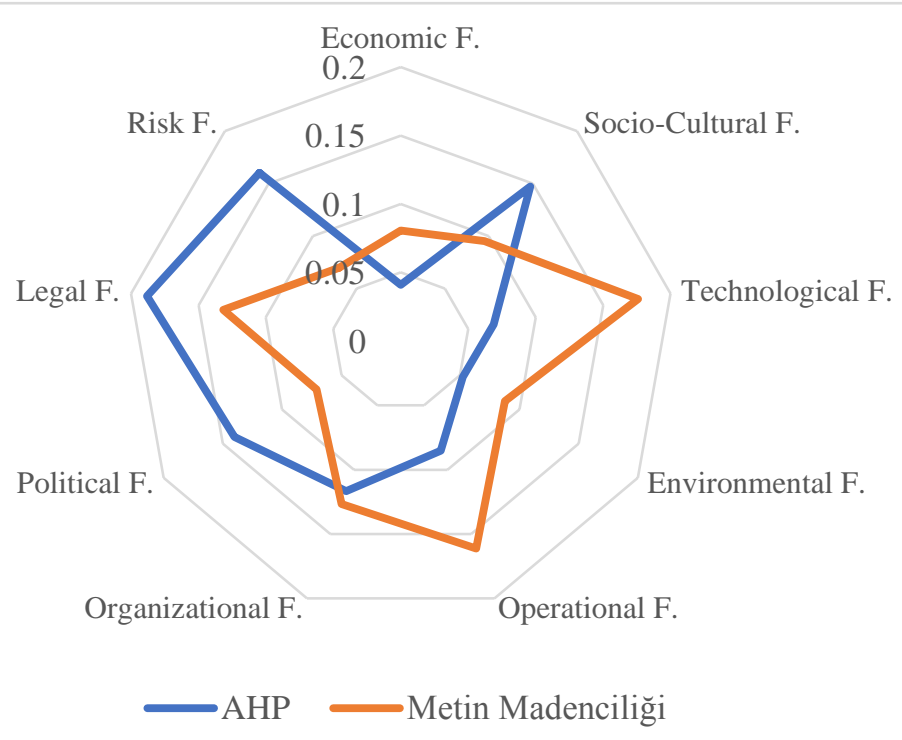

Figure 5 Comparison of Academic and Field Expert Perspectives Based on Main Factors

According to Figure 5, the perspectives of academic and operational experts are mostly coincided in the organizational field and relatively overlapped in economic, socio-cultural, environmental, and legal fields. Major differences of opinion in the areas of technology and risk were reported. The cause of the observed perspective differences in risk factors can be due to the common view of inadequate efforts made in this area and the necessity of their consideration by experts. It is seen that the AHP results reflect the disaster management structure in Turkey relatively and based on these results, the prominence of political factors expressed by experts in the field shows the importance of the role of political actors in the field of disaster management in our country. It can be suggested based on these results that political actors should exert their power in guiding activities in this field.

\subsection{Integrated Analysis Findings}

The critical success factors generated by integrating AHP with text mining results will be discussed in this part, thus the perspective of both operational experts and academic experts will be presented. Each factor's Critical Success Score (CSS) was calculated by multiplying the AHP weights of the main factor group and sub-factor groups with the normalized values derived from the frequency of the factors' publication number by text mining method. It was shown that the first 20 factors with the highest score were above 0.5 when the CSS values were evaluated. It can be concluded, based on this result, that the value of 0.5 can be taken as the threshold value for future studies. Given this situation, 20 factors were 
Cebeci et al.

identified as Critical Success Factors in Disaster Management within the framework of this study, because they have a value higher than 0.5. These factors are shown in Table 7.

Table 7 Critical Success Factors in Disaster Management

\begin{tabular}{|c|c|c|c|c|}
\hline Order & $\begin{array}{l}\text { Main Factor } \\
\text { Group }\end{array}$ & Sub Factor Group & Factor & CSS \\
\hline 1 & Risk & $\begin{array}{l}\text { Risk Factors Related to Disaster } \\
\text { Management }\end{array}$ & Risk Evaluation & 1.727 \\
\hline 2 & Legal & Restrictive Legal Regulations & Terms of References and Regulations & 1.183 \\
\hline 3 & Operational & Pre-Disaster Planning Activities & $\begin{array}{l}\text { Creating a Disaster and Emergency } \\
\text { Plan }\end{array}$ & 1.135 \\
\hline 4 & Legal & Restrictive Legal Regulations & Enactments and Laws & 1.05 \\
\hline 5 & Organizational & $\begin{array}{l}\text { Corporate Disaster Management } \\
\text { Plan }\end{array}$ & $\begin{array}{l}\text { Disaster Management Strategy and } \\
\text { Plan }\end{array}$ & 0.913 \\
\hline 6 & Environmental & $\begin{array}{l}\text { Environmental Disaster } \\
\text { Prevention } \quad \text { Activities }\end{array}$ & Use and Protection of Natural Barriers & 0.9 \\
\hline 7 & Organizational & $\begin{array}{l}\text { Inter-Organizational } \\
\text { Collaboration and Participation }\end{array}$ & Coordination and Collaboration & 0.834 \\
\hline 8 & Risk & $\begin{array}{l}\text { Risk Factors Related to Disaster } \\
\text { Management }\end{array}$ & Infrastructure & 0.806 \\
\hline 9 & Operational & Pre-Disaster Planning Activities & $\begin{array}{l}\text { Statistics and Analysis of Previous } \\
\text { Disasters }\end{array}$ & 0.737 \\
\hline 10 & Political & $\begin{array}{l}\text { Communication and Information } \\
\text { Management }\end{array}$ & Public Advice and Advisory Services & 0.692 \\
\hline 11 & Political & Operational Factors & $\begin{array}{l}\text { Health, Safety and Security } \\
\text { Management }\end{array}$ & 0.674 \\
\hline 12 & Socio-Cultural & Education & $\begin{array}{l}\text { Educational Design (Education } \\
\text { Quality, Training Content) }\end{array}$ & 0.671 \\
\hline 13 & Socio-Cultural & $\begin{array}{l}\text { Social Participation and } \\
\text { Association }\end{array}$ & Rehabilitation & 0.647 \\
\hline 14 & Socio-Cultural & Education & Post-Disaster Response Drills & 0.643 \\
\hline 15 & Legal & Restrictive Legal Regulations & Local Regulations & 0.601 \\
\hline 16 & Socio-Cultural & Education & $\begin{array}{l}\text { Rescue and Healthcare Professional } \\
\text { Training }\end{array}$ & 0.595 \\
\hline 17 & Technological & $\begin{array}{l}\text { Disaster Management Support } \\
\text { Systems }\end{array}$ & Information Management System & 0.545 \\
\hline 18 & Economic & Pre-Disaster Preparation & Pre-Disaster Financial Instruments & 0.541 \\
\hline 19 & Risk & $\begin{array}{l}\text { Pre-Disaster (Related to Disaster) } \\
\text { Risks }\end{array}$ & Geographical Risks & 0.507 \\
\hline 20 & Organizational & $\begin{array}{l}\text { Inter-Organizational } \\
\text { Collaboration and } \\
\text { Participation }\end{array}$ & $\begin{array}{l}\text { Inter-Organizational and External } \\
\text { Communication }\end{array}$ & 0.504 \\
\hline
\end{tabular}

While risk evaluation is the most critical success factor in disaster management, if we look at the table, we see that it is notable that the factors are usually linked to prevention and planning. This proves the statement that pre-disaster prevention and mitigation measures which will mitigate the loss of life and property and minimize the potential impact of disasters are more critical than post-disaster response, rescue, and recovery activities. For this purpose, the need to prepare pre-disaster activities in our country can be suggested to institutions and organizations in the field of disaster management and to political actors who have power and influence in this domain. Table 8 was created to examine in a more general perspective, showing how many critical success factors belong to which main factor group. 
Cebeci et al.

Table 8 Number of CSF Belonging to Main Factor Groups

\begin{tabular}{|l|c|}
\hline \multicolumn{1}{|c|}{ Main Factor Group } & $\begin{array}{c}\text { Number of CSF } \\
\text { that inherits }\end{array}$ \\
\hline Economic Factors & 1 \\
\hline Socio-Cultural Factors & 4 \\
\hline Technological Factors & 1 \\
\hline Environmental Factors & 1 \\
\hline Operational Factors & 2 \\
\hline Organizational Factors & 3 \\
\hline Political Factors & 2 \\
\hline Legal Factors & 3 \\
\hline Risk Factors & 3 \\
\hline
\end{tabular}

The fact that all nine main factor groups include critical success factors in disaster management is an indicator that these main factor groups are correctly determined in the first place and that all areas are relevant. The importance of education in disaster management is demonstrated by the fact that three of the socio-cultural factors belong to the education sub-factor group. For this reason, it can be inferred that disaster management education studies are not only productive in how we can act in times of danger, but also very significant in developing a culture of disaster. The significance of disaster culture education can also be observed in practice in Japan. The readiness culture formed for earthquakes that occur infrequent and unpredictable conditions forms the general culture of the people of Japan in this context. Schools, community centers, and workplaces are equipped with training in disaster management to implement such a culture [54]. Table 8 further highlights the need for disaster management research to have an organizational basis, the requirement to enhance them with legal factors, and to include risk management.

\subsection{Trend Analysis Findings}

Regression analysis was carried out with text mining data to assess the factors in which the focus has shifted toward concerning the academic studies. Defining the focus in the academic field will ensure that this focus is pursued also in practical studies. In this context, while the values related to the number of articles that mentioned the factors suggest the dependent variable in the calculation of the regression slopes, the years are considered as the independent variable. Table 9 shows the top 20 factors with the highest slope value.

Table 9 The Trend of the Number of Publications Concerning the Factors by Years

\begin{tabular}{|c|l|l|l|c|}
\hline Ordering & \multicolumn{1}{|c|}{ Main FG* } & \multicolumn{1}{|c|}{ Sub Factor Group } & \multicolumn{1}{c|}{ Factors } & $\begin{array}{c}\text { Regression } \\
\text { Slope }\end{array}$ \\
\hline $\mathbf{1}$ & Legal & $\begin{array}{l}\text { Restrictive Legal } \\
\text { Regulations }\end{array}$ & $\begin{array}{l}\text { Terms of References and } \\
\text { Regulations }\end{array}$ & 2.377 \\
\hline $\mathbf{2}$ & Legal & $\begin{array}{l}\text { Restrictive Legal } \\
\text { Regulations }\end{array}$ & Enactments and Laws & 2.15 \\
\hline $\mathbf{3}$ & Technological & Information Management & Sharing Information & 2.145 \\
\hline $\mathbf{4}$ & Technological & $\begin{array}{l}\text { Disaster Management } \\
\text { Support Systems }\end{array}$ & Information Management System & 1.748 \\
\hline $\mathbf{5}$ & Environmental & $\begin{array}{l}\text { Environmental Disaster } \\
\text { Prevention Activities }\end{array}$ & $\begin{array}{l}\text { Use and Protection of Natural } \\
\text { Barriers }\end{array}$ & 1.62 \\
\hline $\mathbf{6}$ & Technological & $\begin{array}{l}\text { Disaster Management } \\
\text { Support Systems }\end{array}$ & $\begin{array}{l}\text { Emergency Aid Support } \\
\text { (Information) System }\end{array}$ & 1.6 \\
\hline $\mathbf{7}$ & Organizational & $\begin{array}{l}\text { Inter-Organizational } \\
\text { Collaboration and } \\
\text { Participation }\end{array}$ & $\begin{array}{l}\text { Coordination and Collaboration } \\
\text { (Information) Quality }\end{array}$ & $\begin{array}{l}\text { Disaster Management Strategy } \\
\text { and Plan }\end{array}$ \\
\hline $\mathbf{8}$ & Organizational & $\begin{array}{l}\text { Corporate Disaster } \\
\text { Management Plan }\end{array}$ & $\begin{array}{l}\text { Communication Content } \\
\text { Information Management }\end{array}$ & 1.566 \\
\hline
\end{tabular}


Cebeci et al.

Table 9 The Trend of the Number of Publications Concerning the Factors by Years (cont.)

\begin{tabular}{|c|l|l|l|c|}
\hline $\mathbf{1 0}$ & Operational & $\begin{array}{l}\text { Pre-Disaster Planning } \\
\text { Activities }\end{array}$ & $\begin{array}{l}\text { Creating a Disaster and } \\
\text { Emergency Plan }\end{array}$ & 1.52 \\
\hline $\mathbf{1 1}$ & Technological & $\begin{array}{l}\text { Disaster Management } \\
\text { Support Systems }\end{array}$ & $\begin{array}{l}\text { Projection and Early Warning } \\
\text { Systems }\end{array}$ & 1.478 \\
\hline $\mathbf{1 2}$ & Operational & $\begin{array}{l}\text { Pre-Disaster Planning } \\
\text { Activities }\end{array}$ & $\begin{array}{l}\text { Statistics and Analysis of } \\
\text { Previous Disasters }\end{array}$ & 1.439 \\
\hline $\mathbf{1 3}$ & Operational & $\begin{array}{l}\text { Logistics Act.** Before, } \\
\text { During and After Disaster }\end{array}$ & $\begin{array}{l}\text { Resource Planning and } \\
\text { Management }\end{array}$ & 1.407 \\
\hline $\mathbf{1 4}$ & Economic & Pre-Disaster Preparation & $\begin{array}{l}\text { Pre-Disaster Financial } \\
\text { Instruments }\end{array}$ & 1.324 \\
\hline $\mathbf{1 5}$ & Operational & $\begin{array}{l}\text { Logistics Act.** Before, } \\
\text { During and After Disaster }\end{array}$ & $\begin{array}{l}\text { Logistics Planning and } \\
\text { Management }\end{array}$ & 1.248 \\
\hline $\mathbf{1 6}$ & Risk & $\begin{array}{l}\text { Risk Factors Related to } \\
\text { Disaster Management }\end{array}$ & Risk Evaluation & 1.167 \\
\hline $\mathbf{1 7}$ & Technological & Technological Infrastructure & Logistics Technology & 1.123 \\
\hline $\mathbf{1 8}$ & Legal & $\begin{array}{l}\text { Restrictive Legal } \\
\text { Regulations }\end{array}$ & Local Regulations & 1.118 \\
\hline $\mathbf{1 9}$ & Organizational & Individual Competencies & Leadership & 1.105 \\
\hline $\mathbf{2 0}$ & Technological & $\begin{array}{l}\text { Disaster Management } \\
\text { Support Systems }\end{array}$ & Post-Disaster Response System & 1.13 \\
\hline
\end{tabular}

* Main Factor Group

**Activities

According to the values in Table 9, the slope ratios of the factors of "Terms of References and Regulations", "Enactments and Laws"," Sharing Information "and Information Management System" showed that the academic focus shifted to these factors. The finding that 7 of the first 20 factors with the highest slope value are technological factors illustrates the impact of technological advances on disaster management between 2000-2016. Table 10 displays the slope regression values of the main factor groups and sub-factor groups calculated by the frequency of the factors.

Table 10 The Slope of the Number of Publications in Main Factor Groups and Sub-Factor Groups by Years

\begin{tabular}{|l|l|c|}
\hline \multicolumn{1}{|c|}{$\begin{array}{c}\text { Main Factors } \\
\text { (Regression Slope) }\end{array}$} & \multicolumn{1}{|c|}{ Sub Factor Groups } & Regression Slope \\
\hline Economic Factors & Pre-Disaster Preparation & 2.125 \\
(2.618) & Post-Disaster Response & 0.392 \\
& Macro-Economic Factors & 0.963 \\
\hline \multirow{2}{*}{ Environmental Factors } & Environmental Disaster Prevention Activities & 2.495 \\
(2.691) & Environmental Response After Disasters & 0.441 \\
& Post-Disaster Life & 0.373 \\
\hline \multirow{2}{*}{ Socio-Cultural Factors } & Individual Factors (Qualifications and Skills) & 0.502 \\
(2.674) & Education & 1.157 \\
\hline \multirow{3}{*}{ Technological Factors } & Social Participation and Association & 1.816 \\
(5.336) & Disaster Management Support Systems & 4.13 \\
& Effective Communication During and After & 1.505 \\
\hline \multirow{3}{*}{ Operational Factors } & Disaster & 3.542 \\
(5.086) & Information Management & 2.326 \\
\hline & Technological Infrastructure & 3.402 \\
& Pre-Disaster Planning Activities & 1.044 \\
Organizational Factors & Disaster Response Systems and Activities & 2.027 \\
(3.917) & Post-Disaster Recovery (Rescue) Operations & 2.245 \\
& Logistics Act. Before, During, and After Disaster & 2.005 \\
\hline
\end{tabular}


Cebeci et al.

Table 10 The Slope of the Number of Publications in Main Factor Groups and Sub-Factor Groups by Years (cont.)

\begin{tabular}{|l|l|c|}
\hline Political Factors & Communication and Information Management & 1.426 \\
$(2.071)$ & Operational Factors & 1.179 \\
\hline Legal Factors & Restrictive Legal Regulations & 3.998 \\
(3.998) & Factors Related to the Implementation of Laws & 0.069 \\
\hline Risk Factors & Pre-Disaster (Related to Disaster) Risks & 0.645 \\
$(2.105)$ & Risk Factors Related to Disaster Management & 1.904 \\
\hline
\end{tabular}

As seen in Table 10, The finding that technological and operational factors have the greatest slope value is an indicator of the need to concentrate on these two fields in practice. The observation that disaster management studies also pursue technological advances is not an unforeseen outcome. Academic articles draw attention to the preparation process to include the pre-disaster, during, and post-disaster phases and the execution of the practices in the light of these preparations. Again, the legal factors coincide with the results of the AHP analysis, with a very high slope ratio. Since the organizational factors have a similar ratio and high ranking, this indicates that disaster management should have an organizational base. These results may guide the implementation of disaster management practices in Turkey particularly. Furthermore, since there is a positive slope in all the main factor groups this suggests that disaster management research in these particular nine groups gained greater value over the years.

When evaluated on the basis of sub-factor group, the "Disaster Management Support Systems" subfactor group belonging to the technological factors has the highest slope value. This situation shows those decision support systems, which have become important in every field as a result of today's technological developments, are also reflected in the field of disaster management within the scope of this study. As "Restrictive Legal Regulations," another sub-factor group stands out as having a high slope value. This may mean the need for legal regulations, such as the establishment of standards for structural or environmental problems that pose a threat to disaster management. In general, there is a positive slope for each sub-factor group.

The above findings provide thorough guidance for successful disaster management in Turkey and offer results that allow the introduction of helpful suggestions. These findings are obtained as a result of a study aimed at building a new model that would not overlook the opinions of operational experts in Turkey and as well as the academic studies in this area.

\section{Results}

In the area where they happen, disasters can cause loss of life and property and economic losses that extend beyond the boundaries of that region. Disaster management corresponds to an infinite process consisting of pre-disaster, during disaster and post-disaster activities to minimize or avoid such losses. This process is directly affected by activities such as the availability of the required resource requirements, the formation of a social system ready for a disaster in a socio-cultural context, and technological advances.

In this study carried out for determining the critical factors for having a successful disaster management structure, it has been concluded that 9 areas which are economic, environmental, socio-cultural, technological, operational, organizational, political, legal, and risk affect the success of disaster management. The literature review for each of these areas has demonstrated that the success of disaster management is influenced by several factors. Through putting together the identified factors that have similar characteristics in the main areas, a new grouping was formed. As shown in the proposed model, a hierarchy was created, with 9 main areas at the first level, sub-factor groups at the second level, and factors at the third level. AHP method was utilized for the first two levels of the hierarchy during the application of the study. For AHP management, data obtained from experts in the field of disaster management was used. For the third level, the text mining method was used to add academic knowledge to the model by analyzing the perspective of academic experts. Critical success factors have been 
obtained as a result of the integration of these two methods, which incorporate the expertise of these two different disaster management expert groups into a single melting pot.

As a result of AHP analysis, the shining out of legal factors in main factor groups, this can be interpreted by stating that disaster management works in Turkey will be functional if a legal basis is provided. Therefore, at this point, devoted efforts in the field of disaster management should be made by legislators in Turkey. Since the legal factors have also been discussed by academic studies, this can be seen in conjunction with the results of the AHP and highlight the significance of disaster management legislation in many parts of the world, not just in Turkey. In particular, the views of field experts focused on the need for education suggest that educational research should be reinforced by legislation and it is an essential requirement to set up an education system that would make instruction in disaster management mandatory.

According to text mining research, when reviewing the advancements in the technology sector today, the prevalence of technological factors is not a surprising outcome. In particular, the attention shown on the Disaster Management Support Systems is an indicator of the possible contribution that decisionsupport systems can offer to the disaster management. Via text mining analyses, the operational factor group has also stepped forth. This outcome matches the operational system's continuous improvement factor, which is identified by Zhou, Huang, and Zhang [6] as one of the critical success factors in disaster management. Therefore, it can be suggested to disaster management institutions in the world and Turkey to plan the operations that take place at each stage of the disaster management cycle in a feasible manner. Besides, the rising importance of slope factors over the years suggests that the focus has shifted to these two main groups of factors, which are more measurable and manageable. In terms of converting theoretical knowledge into practice in disaster management, these conclusions should be kept in mind.

Determining the risk evaluation factor as the most critical success factor after integrating both analysis methods shows that the pre-disaster process is quite crucial. The results of this study also affirm that pre-disaster research should include activities of risk assessment. The obtained results can be outlined based on the findings of the study, that disaster management should be assisted by enactments and laws, the terms of references and regulations that promote the implementation of the laws should be taken into account, and that plans should be designed to be ready for disasters and emergencies and that all these risks evaluations should be included in the process.

Highlighting the coordination and sufficient financial support in disaster management by Ophiyandri et al. [5] and emphasize of the financing plan in the study by Liu, Scheepbouwer, and Giovinazzi [4], in which critical success factors for infrastructure recovery after disasters are determined, coincide with the critical success factors obtained as a result of this study. To facilitate the sharing of the collected data among planners, designers, operators, and decision-makers, Liu, Scheepbouwer, and Giovinazzi [4] also defined the standardization of the data management mechanism as a critical success factor. Likewise, the identification of an effective emergency information system by Zhou, Huang, and Zhang [6] as one of the five critical success factors consistent with the findings of this study, which shows the value of the information management system.

While the critical success factors for disaster management defined within the framework of the study may provide practical benefits to the further research in this area, the identification of prominent factors within the groups may guide the studies carried out on a group basis. Furthermore, with the guidance of the literature, the presence of critical success factors in each of the nine main factor groups confirms that an appropriate grouping has been achieved. The following suggestions can be proposed in this context to lead future studies:

- Through accessing studies in other databases, the examined publication sample may be extended.

- Perspectives of people exposed to disasters can also be included in the study model.

- It is possible to not completely grasp the factors interacting with each other in the hierarchical structure. In this context, with different analytical methods, such as ANP (Analytical Network Process), which takes interaction into account, the model can be extended.

- With distinct methods, such as NLP (Natural Language Processing), the text mining approach can be structured. 


\section{References}

[1] O. Ergünay, “Afet Yönetimi: Genel İlkeler Tanımlar Kavramlar,” first ed., Ankara, 2009.

[2] Afet ve Acil Durum Yönetimi Başkanlığı, "Açıklamalı afet yönetimi terimleri sözlüğü,” 2020. Available: https://www.afad.gov.tr/aciklamali-afet-yonetimi-terimleri-sozlugu [Accessed 10 July 2020].

[3] B. Hidayat, C. Egbu, "Critical success factors associated with post-disaster reconstruction projects," in: Proceedings of the 27th Annual Association of Researchers in Construction Management (ARCOM) Conference - Bristol, UK, pp. 889-898, 2011.

[4] M. Liu, E. Scheepbouwer, S. Giovinazzi, "Critical success factors for post-disaster infrastructure recovery: Learning from the Canterbury (NZ) Earthquake Recovery,” Disaster Prevention and Management, vol. 25, no. 5, pp. 685-700, 2016. https://doi.org/10.1108/DPM-01-2016-0006.

[5] T. Ophiyandri, D. Amaratunga, C. Pathirage, K. Keraminiyage, "Critical success factors for community-based post-disaster housing reconstruction projects in the pre-construction stage in Indonesia," International Journal of Disaster Resilience in the Built Environment, vol. 4, no. 2, pp. 236-249, 2013. https://doi.org/10.1108/IJDRBE-03-2013-0005.

[6] Q. Zhou, W. Huang, Y. Zhang, "Identifying critical success factors in emergency management using a Fuzzy DEMATEL Method,” Safety Science, vol. 49, no. 2, pp. 243-252, 2011. https://doi.org/10.1016/j.ssci.2010.08.005.

[7] D. van Niekerk, "Disaster risk reduction, disaster risk management and disaster management: Academic rhetoric or practical reality?,” Disaster Management: South Africa, vol. 4, no. 1, pp. 69, 2007.

[8] National Institute of Disaster Management, “Understanding disasters," 2020. Available: http://nidm.gov.in/PDF/Disaster_about.pdf [Accessed 10 January 2020].

[9] J. Herrmann, "Disaster response planning \& preparedness: Phases of disaster," in: S. Harding (Eds.), NYDIS Manual For New York City Religious Leaders: Spiritual Care and Mental Health for Disaster Response and Recovery, New York Disaster Interfaith Servies (NYDIS), New York, pp. 11-14, 2007.

[10] M. Kadioğlu, “Afet Yönetimi: Beklenilmeyeni Beklemek En Kötüsünü Yönetmek,” first ed., T.C. Marmara Belediyeler Birliği Yayın, İstanbul, 2011.

[11] D. Ozceylan, E. Coskun, "Defining critical success factors for national emergency management model and supporting the model with information systems," in: Proceedings of the 5th International ISCRAM Conference - Washington, DC, USA, pp. 376-383, 2008.

[12] J. S. Chou, J. H. Wu, "Success factors of enhanced disaster resilience in Urban Community," Natural Hazards, vol. 74, no. 2, pp. 661-686, 2014. https://doi.org/10.1007/s11069-014-1206-4.

[13] C. Pathirage, K. Seneviratne, D. Amaratunga, R. Haigh, "Knowledge factors and associated challenges for successful disaster knowledge sharing," Prepared for the Global Assessment Report on Disaster Risk Reduction 2015, pp. 1-30, 2014.

[14] K. Seneviratne, C. Pathirage, D. Amaratunga, R. Haigh, "Disaster knowledge factors: Benefits and challenges," in: Proceedings of International Conference on Building Resilience 2011 Kandalama, Sri Lanka, 2011.

[15] K. Seneviratne, D. Amaratunga, R. Haigh, C. Pathirage, "Knowledge management for disaster resilience: Identification of the key success factors," in: Proceedings of CIB World Congress 2010 - Salford, United Kingdom, 2010.

[16] Y. A. Ahmed, M. N. Ahmad, N. H. Zakaria, "Knowledge sharing framework for disaster management," Journal of Information Systems Research and Innovation, vol. 9, no. 1, pp. 50-60, 2015.

[17] A. Yavuz, S. Dikmen, "Doğal afetlerin zararlarının finasmanında kullanılan afet öncesi finansal araçlar," Marmara University Journal of Political Science, vol. 3, no. 2, pp. 303-322, 2015. https://doi.org/10.14782/sbd.2015216101.

[18] S. Chow, "Success factors for IS disaster recovery planning in Hong Kong," Information management \& Computer Security, vol. 8, no. 2, pp. 80-87, 2000. https://doi.org/10.1108/09685220010321326. 
[19] D. Ismail, T. A. Majid, R. Roosli, N. A. Samah, "Project management success for post-disaster reconstruction projects: International NGOs perspectives," Procedia Economics and Finance, vol. 18, pp. 120-127, 2014. https://doi.org/10.1016/S2212-5671(14)00921-6.

[20] J. Andersen, "Globalization and natural disasters: An integrative risk management perspective," in: A. Kreimer, M. Arnold, A. Carlin (Eds.), Building Safer Cities: The Future of Disaster Risk, World Bank Publications, Washington, D.C., pp. 57-74, 2003.

[21] P. Boer, "The Real Options Solution: Finding Total Value in a High-Risk World", first ed., Wiley, New Jersey, 2002.

[22] H. Srinivas, Y. Nakagawa, "Environmental implications for disaster preparedness: Lessons learnt from the Indian Ocean Tsunami,” Journal of Environmental Management, vol. 89, no. 1, pp. 4-13, 2008. https://doi.org/10.1016/j.jenvman.2007.01.054.

[23] S. Sonak, P. Pangam, A. Giriyan, "Green reconstruction of the tsunami-affected areas in India using the integrated coastal zone management concept," Journal of Environmental Management, vol. 89, no. 1,pp. 14-23, 2008. https://doi.org/10.1016/j.jenvman.2007.01.052.

[24] T. O. Owolabi, C. O. Ekechi, "Communication as critical factor in disaster management and sustainable development in Nigeria," International Journal of Development and Economic Sustainability, vol. 2, no. 3, pp. 58-72, 2014.

[25] N. Carter, “Disaster Management: A disaster manager's handbook,” first ed., Asian Development Bank, Philippines, 2008.

[26] International Strategy for Disaster Reduction, "Living With Risk: A Global Review of Disaster Reduction Initiatives,” vol. 1, Genewa, 2004.

[27] S. Chow, W. On Ha, "Determinants of the critical success factor of disaster recovery planning for information systems,” Information Management \& Computer Security, vol. 17, no. 3, pp. 248-275, 2009. https://doi.org/10.1108/09685220910978103.

[28] Y. Li, Y. Hu, X. Zhang, Y. Deng, S. Mahadevan, “An evidential DEMATEL method to identify critical success factors in emergency management," Applied Soft Computing, vol. 22, pp. 504-510, 2014. https://doi.org/10.1016/j.asoc.2014.03.042.

[29] N. Nazli, S. Sipon, A. R. Zumrah, S. Abdullah, "The factors that influence the transfer of training in disaster preparedness training: A review,” Procedia-Social and Behavioral Sciences, vol. 192, pp. 54-58, 2015. https://doi.org/10.1016/j.sbspro.2015.06.008.

[30] M. Col, "Managing disasters: The role of local government," Public Administration Review, vol. 67, pp. 114-124, 2007. https://doi.org/10.1111/j.1540-6210.2007.00820.x.

[31] R. Dahlan, H. M. Dahan, Y. M. Saman, "The success factors for government information sharing (GIS) in natural disaster management and risk reduction," in: Proceedings of the 5th International Conference on Information and Communication Technology for the Muslim World - Sarawak, Malaysia, 2013. https://doi.org/10.1109/ICT4M.2013.6518927.

[32] S. Donald, "Connecting to Disasters": The Critical Success Factors of Mobile Phone Utilisation within Disaster Management Operations: The Case of Vanuatu, Master's Theses at Victoria University of Wellington School of Geography, Environment and Earth Sciences - Wellington, New Zealand, 2012.

[33] R. Oloruntoba, "An analysis of the cyclone larry emergency relief chain: Some key success factors," International Journal of Production Economics, vol. 126, no. 1, pp. 85-101, 2010. https://doi.org/10.1016/j.ijpe.2009.10.013.

[34] F. Arain, "Knowledge-based approach for sustainable disaster management: Empowering emergency response management team,” Procedia Engineering, vol. 118, pp. 232-239, 2015. https://doi.org/10.1016/j.proeng.2015.08.422.

[35] J. R. Harrald, “Agility and discipline: Critical success factors for disaster response,” The Annals of the American Academy of Political and Social Science, vol. 604, no. 1, pp. 256-272, 2006. https://doi.org/10.1177/0002716205285404.

[36] R. Dahlan, H. M. Dahan, M. Y. Saman, "The success factors in government information sharing (GIS) - empirical findings from the Malaysians Natural Disaster Management Context,” in: Proceedings of the 5th International Conference on Information and Communication Technology for The Muslim World - Sarawak, Malaysia, 2013. https://doi.org/10.1109/ICT4M.2014.7020642. 
[37] T. Lin Moe, P. Pathranarakul, "An integrated approach to natural disaster management: Public project management and its critical success factors," Disaster Prevention and Management: An International Journal, vol. 15, no. 3, pp. 396-413, 2006. https://doi.org/10.1108/09653560610669882.

[38] International Strategy for Disaster Reduction, "Hyogo Framework for Action 2005-2015: Building the Resilience of Nations and Communities to Disasters," World Conference on Disaster Reduction - Hyogo, Japan, 2005.

[39] C. Pathirage, K. Seneviratne, D. Amaratunga, R. Haigh, "Managing disaster knowledge: Identification of knowledge factors and challenges," International Journal of Disaster Resilience in the Built Environment, vol. 3, no. 3, pp. 237-252, 2012. https://doi.org/10.1108/17595901211263620.

[40] M. Arain, "An information technology (IT) based approach for enhancing prompt and effective post-disaster reconstruction,” Business Review, vol. 6, no. 2,pp. 67-79, 2011.

[41] A. Arnell, "Handbook of Effective Disaster/Recovery Planning: A Seminar-Workshop Approach," first ed., McGraw-Hill, New York, 1990.

[42] E. Caymaz, F. V. Akyon, F. Erenel, "A model proposal for efficient disaster management: The Turkish Sample,” Procedia-Social and Behavioral Sciences, vol. 99, pp. 609-618, 2013. https://doi.org/10.1016/j.sbspro.2013.10.531.

[43] B. Hansen, "Buildings: Simple, economical house design to resist future tsunamis," Civil Engineering - ASCE, vol. 78, no. 8, pp. 13-14, 2005.

[44] D. Guha-Sapir, R. Below, "The quality and accuracy of disaster data: A comparative analyses of three global data sets," in: for The ProVention Consortium The Disaster Management Facility, The World Bank - Brussels, Belgium, pp. 1-18, 2002.

[45] O. Ergünay, P. Gülkan, H. Güler, "Afet yönetimi ile ilgili terimler açıklamalı sözlük," in: M. Kadıŏlu, E. Özdamar (Eds.), Afet Zararlarını Azaltmanın Temel İlkeleri, Japonya Uluslararası İşbirliği Ajansı Türkiye Ofisi, Ankara, pp. 301-353, 2008.

[46] R. Youker, "Managing international development projects: Lessons learned," Project Management Journal, vol. 30, no. 2, pp. 6-7, 1999. https://doi.org/10.1177/875697289903000202.

[47] R. Oloruntoba, "A wave of destruction and the waves of relief: Issues, challenges and strategies," Disaster Prevention and Management: An International Journal, vol. 14, no. 4, pp. 506-521, 2005. https://doi.org/10.1108/09653560510618348.

[48] X. Chen, M. P. Kwan, Q. Li, J. Chen, "A model for evacuation risk assessment with consideration of pre-and post-disaster factors," Computers Environment and Urban Systems, vol. 36, no. 3, pp. 207-217, 2011. https://doi.org/10.1016/j.compenvurbsys.2011.11.002.

[49] M. Goerigk, K. Deghdak, P. Heßler, "A comprehensive evacuation planning model and genetic solution algorith," Transportation Research Part E: Logistics and Transportation Review, vol. 71, pp. 82-97, 2014. https://doi.org/10.1016/j.tre.2014.08.007.

[50] F. Rockart, "Chief executives define their own data needs," 1979. Available: https://hbr.org/1979/03/chief-executives-define-their-own-data-needs [Accessed 11 January 2020].

[51] S. S. Rad, "Critical success factors (CSFs) in strategic planning for information systems," Journal of Applied Environmental and Biological Sciences, vol. 5, no. 6, pp. 334-339, 2015.

[52] T. L. Saaty, "How to make a decision: The analytic hierarchy process," Interfaces, vol. 24, no. 6, pp. 19-43, 1994. https://doi.org/10.1287/inte.24.6.19.

[53] M. Timor, "Analitik Hiyerarşi Prosesi," first ed., Türkmen Kitabevi, İstanbul, 2011.

[54] S. Tripathi, "Disaster and its socio-cultural implication: A study with culture and personality approach of anthropology (With special reference to disaster in Japan)," Asian Academic Research Journal of Social Sciences \& Humanities, vol. 1, no. 16, pp. 58-64, 2013. 